\title{
A CLINICOPATHOLOGICAL STUDY AND MANAGEMENT OF CARCINOMA PANCREAS
}

\author{
Paatneedi Naresh Kumar1, Ravula Maha Lakshmi², Gonugunta Sri Ranga Sai Karthik ${ }^{3}$
}

${ }^{1}$ Associate Professor, Department of General Surgery, Rangaraya Medical College, Kakinada.

2 Professor, Department of General Surgery, Rangaraya Medical College, Kakinada.

${ }^{3}$ Postgraduate Student, Department of General Surgery, Rangaraya Medical College, Kakinada.

\begin{abstract}
\section{BACKGROUND}

Pancreatic cancer is the ninth most common cancer and is fourth most common cause of cancer related death. More than $85 \%$ of pancreatic cancers are ductal adenocarcinoma. They arise most commonly from the head. They are mostly scirrhous tumours characterised by neoplastic glands with marked desmoplastic fibrous stroma. Even for patients with a tumour that has been surgically removed, local and systemic recurrence is common and the median survival is only 17 - 23 months.

Aims- To study the epidemiology of pancreatic malignancies. To study the time of presentation and operability in the patients with carcinoma pancreas presenting to GGH, Kakinada. Role of various investigative modalities in diagnosing pancreatic cancers. Types of treatment given (curative resections, palliations and chemo and radiotherapy). Morbidity of the patients undergoing surgical treatment. Survival of patients with various modalities of treatment. Post-operative followup.
\end{abstract}

\section{MATERIALS AND METHODS}

A prospective study was conducted among patients admitted to surgical wards in Government General Hospital, Kakinada with imaging suggestive of mass in pancreas during the time period of July 2014 to October 2016.

\section{RESULTS}

The mean age of presentation is 49.71 yrs. Pancreatic cancers appear to be more common in men. Of the 38 patients studied 36 patients had adenocarcinoma, 1 patient had pseudopapillary tumour and 1 patient had main duct IPMN. The most common symptom with which patients presented is Jaundice (87\%) followed by loss of weight and appetite (79\%). Pseudopapillary tumour and cystic neoplasm of pancreas did not present with jaundice. Gallbladder was palpable in 19 cases (50\%). Vomiting occurred in 4 patients who developed gastric outlet obstruction. Number of patients in whom CECT was suggestive of an operable tumour, but intraoperatively tumour was inoperable are $9 / 27$. Among the 38 cases studied, only 17 patients had raised CA19-9 levels, which is around 44.73\%. Definitive procedure was done in 18 patients, whereas palliative surgery was done in 9 patients.

Complications- The most common complication after pancreatic resections is surgical site infection. Other complications encountered are pancreatic leaks, delayed gastric emptying, reactionary haemorrhage and precipitation of other medical conditions like CCF; 2 patients died in post-operative period $3^{\text {rd }}$ and $6^{\text {th }}$ day. In the present study, the mean survival among the operative group is 11.68 months compared to 4.06 months in palliative group. There is a clear overall survival in patients post resection; 12 patients are still in followup, 7 of whom underwent palliative procedure and patients underwent resection.

\section{CONCLUSION}

- Males compared to females suffered more in the ratio of 23:15.

- There is steady increase in the incidence of pancreatic malignancies with age with peak incidence between 50 - 60 yrs.

- Jaundice followed by loss of weight and loss of appetite are the most common symptoms.

- Elevated bilirubin with palpable gallbladder is seen in $50 \%$ of cases only.

- USG abdomen is a useful screening method for identification of dilated CBD and presence or absence of mass lesion of pancreas and to see for any distension of gallbladder.

- Dilated CBD with mass in the head of pancreas is the most common imaging finding.

- Most of the patients present late and more than half (52.63\%) presented with a Metastatic disease.

- Pancreatic protocol CECT abdomen is used for determining preoperative resectability and had significant false positives $(9 / 25)$.

- Most common surgery done in our department is PPPD, followed by distal pancreatectomy and high number of palliative procedures.

- Surgeries for pancreatic malignancies have high morbidity due to the poor patient reserve and advanced stage of presentation.

- Even after a successful resection of the tumour, in followup the 1 year survival rate is $55.55 \%$.

- Due to the advanced presentation, most of the patients have poor outcome following pancreatic surgeries. So high index of suspicion should guide towards USG screening in elderly patients with H/o smoking and loss of weight and appetite with or without jaundice.

\section{KEYWORDS}

Carcinoma Pancreas, Epidemiology, Types of Surgeries, Followup.

HOW TO CITE THIS ARTICLE: Kumar PN, Lakshmi RM, Karthik GSRS. A clinicopathological study and management of carcinoma pancreas. J. Evolution Med. Dent. Sci. 2017;6(27):2225-2230, DOI: 10.14260/Jemds/2017/480 
Financial or Other, Competing Interest: None.

Submission 16-12-2016, Peer Review 17-02-2017,

Acceptance 23-02-2017, Published 01-04-2017.

Corresponding Author:

Dr. Paatneedi Naresh Kumar,

10-5-27/1, Nageswar Rao Street,

Ramaraopeta, Kakinada, Andhra Pradesh.

E-mail: drnaresh180532@yahoo.com

DOI: $10.14260 /$ jemds $/ 2017 / 480$

\section{(c) $(1) \risingdotseq$}

\section{BACKGROUND}

The earliest known description of pancreatic cancer was provided in 1761 by Giovanni Battista Morgagni, an Italian pathologist at the University of Padua.[1] In 1858, Jacob Mendez Da Costa, a Philadelphia clinician pathologist, revisited Morgagni's original work and made a substantial contribution to the subject of pancreatic neoplasia by recording several cases of pancreatic cancer with one of these cases having a microscopic diagnosis of adenocarcinoma.[2] In 1898, the Italian surgeon Alessandro Codivilla performed the first reported pancreaticoduodenectomy for head of pancreas tumour, but patient did not survive the post-operative period. William Halsted performed the first successful resection of ampullary cancer by excising portions of duodenum and pancreas.(3) In 1912 Walther Carl Eduard Kausch, a German surgeon performed first successful pancreaticoduodenectomy in two stages.(4) Two years later, Georg Hirschel described the first successful pancreaticoduodenectomy in one stage.(5) For palliation, antitumour activity of \% fluorouracil in pancreatic cancer was reported in 1960s.(6) In 1997, Gemcitabine emerged as a new reference treatment in advanced pancreatic cancer with increased DFS and OS compared to 5-fluorouracil.(7)

Pancreatic resections are major surgeries with morbidity and pancreatic malignancies have poor prognosis. So study on this is done in GGH, Kakinada to study the aetiology, epidemiology, modes of presentation, operability of tumour at presentation, types of surgeries, outcomes postoperatively and long-term followup.

\section{MATERIALS AND METHODS}

A prospective study was conducted among patients admitted to surgical wards in Government General Hospital, Kakinada with imaging suggestive of mass in pancreas during the time period of July 2014 to October 2016.

\section{Method of Collection of Data}

Data was collected from patient's records regarding age, sex incidences, modes of presentation, various investigations done, types of surgeries performed, post-operative complications and followup of patients. Inoperable patients either because of locally advanced disease or metastasis were sent for palliative therapy.

\section{Inclusion and Exclusion Criteria}

All the patients who had imaging suggestive of solid/cystic mass in the head, body or tail of pancreas which are confirmed by surgery are included in my study; ( 2 patients underwent Whipple's PD and post-operative biopsy came negative for malignancy, these cases are not included in the study).
Tumours in the periampullary region are included in this study, as most of these (>50\%) arise from head of pancreas.

Endocrine tumours of pancreas are excluded from the study as diagnosis and presentation are rare.

\section{RESULTS}

\section{Age Incidence}

The youngest of pancreatic cancer in my study is 15 years old, who had a pseudopapillary (Frantz) tumour and oldest age of patient affected is 72 yrs. The mean age of presentation is 49.71 yrs.; 2 patients who had pancreatic cancer at early age had recurrent chronic pancreatitis and mass formation in head of pancreas.

\begin{tabular}{|c|c|c|}
\hline Age & No. of Patients & Percentage \\
\hline$<30$ yrs. & 5 & $13.1 \%$ \\
\hline $31-40$ yrs. & 4 & $10.5 \%$ \\
\hline $41-50$ yrs. & 10 & $26.31 \%$ \\
\hline $51-60$ yrs. & 12 & $31.57 \%$ \\
\hline $61-70$ yrs. & 6 & $15.78 \%$ \\
\hline $71-80$ yrs. & 1 & $2.63 \%$ \\
\hline
\end{tabular}

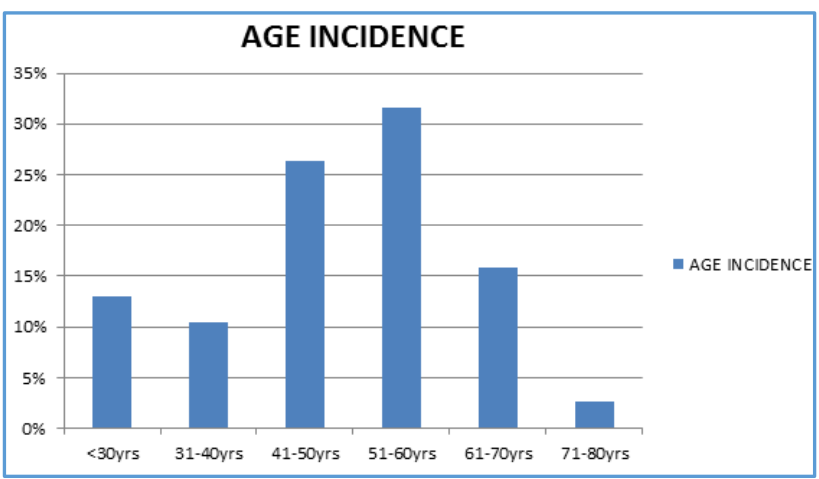

\section{Sex Incidence}

In my study, pancreatic cancers appear to be more common in men and ratio of incidence to males and females is $60.5 \%$ and $39.5 \%$ respectively.

\begin{tabular}{|c|c|c|}
\hline Sex & Number of Patients & Percentage \\
\hline Male & 23 & $60.5 \%$ \\
\hline Female & 15 & $39.5 \%$ \\
\hline
\end{tabular}

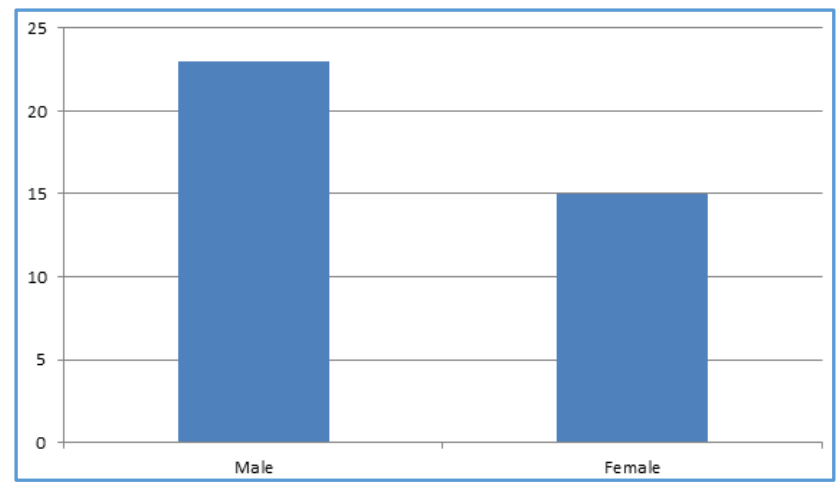

\section{Type of Malignancy}

Of the 38 patients studied 36 patients had adenocarcinoma, 1 patient had pseudopapillary tumour and 1 patient had main duct IPMN. 


\begin{tabular}{|c|c|c|}
\hline Type of Tumour & No. of Patients & $\mathbf{\%}$ \\
\hline Adenocarcinoma & 36 & $94.7 \%$ \\
\hline Pseudopapillary tumour & 1 & $2.6 \%$ \\
\hline IPMN & 1 & $2.6 \%$ \\
\hline
\end{tabular}

\section{Smoking and Alcohol}

25 patients $(65.18 \%)$ among 38 studied have past history or smokers at present and 24 (63.15\%) patients are alcoholics; 2 patients had history of chronic pancreatitis and they had incidence of pancreatic cancer at an early age ( $<40 \mathrm{yrs}$.).

\begin{tabular}{|c|c|c|}
\hline & No. of Patients & \% \\
\hline Smokers & 25 & $65.78 \%$ \\
\hline Alcoholics & 24 & $63.15 \%$ \\
\hline
\end{tabular}

\section{Clinical Features}

The most common symptom with which patients presented is Jaundice $(87 \%)$ followed by loss of weight and appetite (79\%). Pseudopapillary tumour and cystic neoplasm of pancreas did not present with jaundice. Gallbladder was palpable in 19 cases (50\%). Vomitings occurred in 4 patients, who developed gastric outlet obstruction.

\begin{tabular}{|c|c|c|}
\hline Sign/Symptom & No. of Patients & Percentage \\
\hline Jaundice & 33 & $86.84 \%$ \\
\hline Loss of weight/appetite & 30 & $78.94 \%$ \\
\hline Pain abdomen & 25 & $65.78 \%$ \\
\hline Melena & 8 & $21.07 \%$ \\
\hline Palpable gallbladder & 19 & $50 \%$ \\
\hline Vomiting & 4 & $10.5 \%$ \\
\hline
\end{tabular}

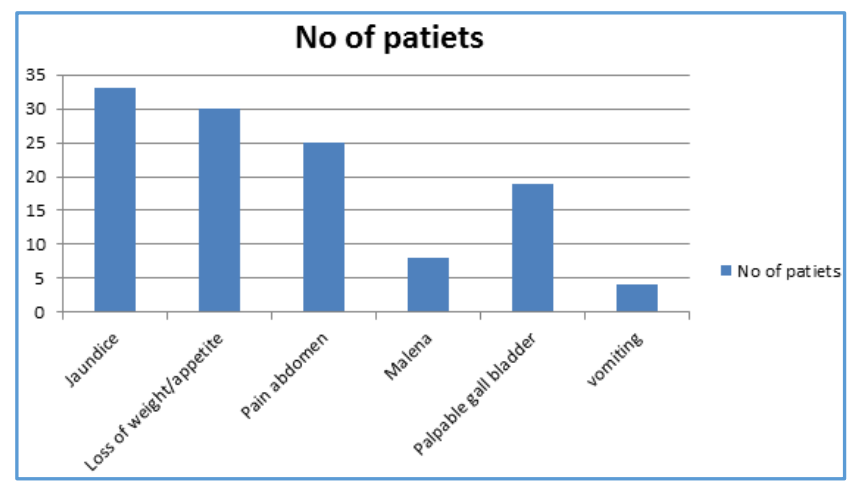

Number of patients in whom CECT was suggestive of an operable tumour, but intraoperatively tumour was inoperable are $9 / 27$.

\begin{tabular}{|l|c|c|c|}
\hline & Operable & $\begin{array}{c}\text { Inoperable } \\
\text { Cases }\end{array}$ & $\begin{array}{c}\text { \% of False } \\
\text { Positives }\end{array}$ \\
\hline CECT Findings & 27 & 9 & $23.3 \%$ \\
\hline
\end{tabular}

\section{Pancreatico-Enteric Anastomosis}

In the 38 cases studied 16 patients underwent Whipple's surgery, of which 13 patients (81.25\%) underwent pancreatico-jejunostomy (mucosa to mucosa anastomosis) and 3 patients (18.75\%) underwent pancreatico-gastrostomy (dunking). There was no significant difference in post-op morbidity or leak rates in both procedures.

\begin{tabular}{|c|c|c|}
\hline $\begin{array}{c}\text { Type of Pancreatico-Enteric } \\
\text { Anastomosis }\end{array}$ & $\begin{array}{c}\text { No. of } \\
\text { Cases }\end{array}$ & \% \\
\hline PJ (mucosa to mucosa) & 13 & $81.25 \%$ \\
\hline PG (dunking) & 3 & $18.75 \%$ \\
\hline
\end{tabular}

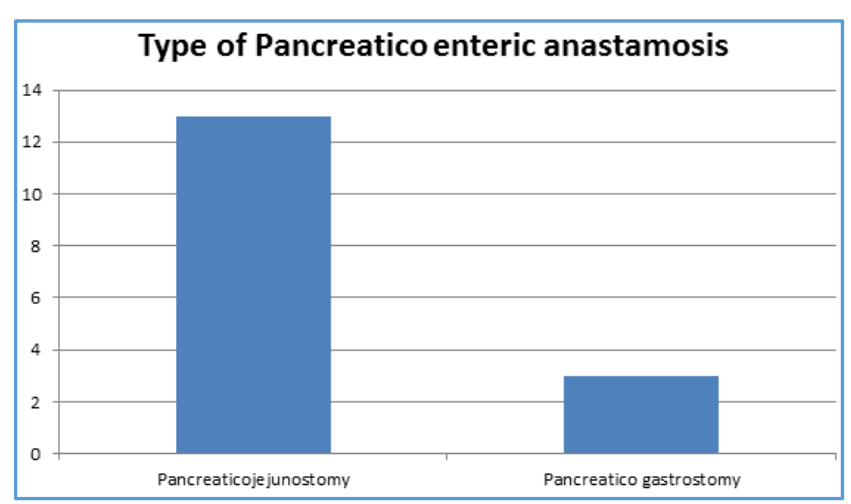

Role of CA19-9

Among the 38 cases studied only 17 patients had raised CA19-9 levels, which was around 44.73\%.

\begin{tabular}{|c|c|c|}
\hline Levels of CA19-9 & No. of Patients & \% of Patients \\
\hline Increased & 17 & $44.73 \%$ \\
\hline Normal & 21 & $55.26 \%$ \\
\hline
\end{tabular}

\section{ERCP and Stenting}

All the patients underwent side-viewing scopy and biopsies were taken for all the patients who had ulcerated papilla. For all inoperable cases stenting was done and for patient with high bilirubin stenting was done even if the patient was operable. Two inoperable cases were not stented, as they had involvement of duodenum D2 and ERCP could not be done.

\begin{tabular}{|c|c|c|}
\hline ERCP Stenting & $\begin{array}{c}\text { No. of } \\
\text { Patients }\end{array}$ & $\begin{array}{c}\text { \% of } \\
\text { Patients }\end{array}$ \\
\hline $\begin{array}{c}\text { Operable patients } \\
\text { (Pre-operatively) }\end{array}$ & $20 / 27$ & $74 \%$ \\
\hline Inoperable patients & $9 / 11$ & $81.8 \%$ \\
\hline
\end{tabular}

Various Definitive and Palliative Procedures Done

\begin{tabular}{|c|c|c|}
\hline Type of Surgery & $\begin{array}{c}\text { No. of } \\
\text { Patients }\end{array}$ & \% \\
\hline Whipple's resection & 16 & $42 \%$ \\
\hline Distal Pancreatectomy & 2 & $5.2 \%$ \\
\hline Palliative HJ & 3 & $7.8 \%$ \\
\hline Triple bypass & 3 & $7.8 \%$ \\
\hline Cholecystojejunostomy & 1 & $2.6 \%$ \\
\hline $\begin{array}{c}\text { Cholecystojejunostomy + } \\
\text { Gastrojejunostomy }\end{array}$ & 1 & $2.6 \%$ \\
\hline Gastrojejunostomy & 1 & $2.6 \%$ \\
\hline
\end{tabular}




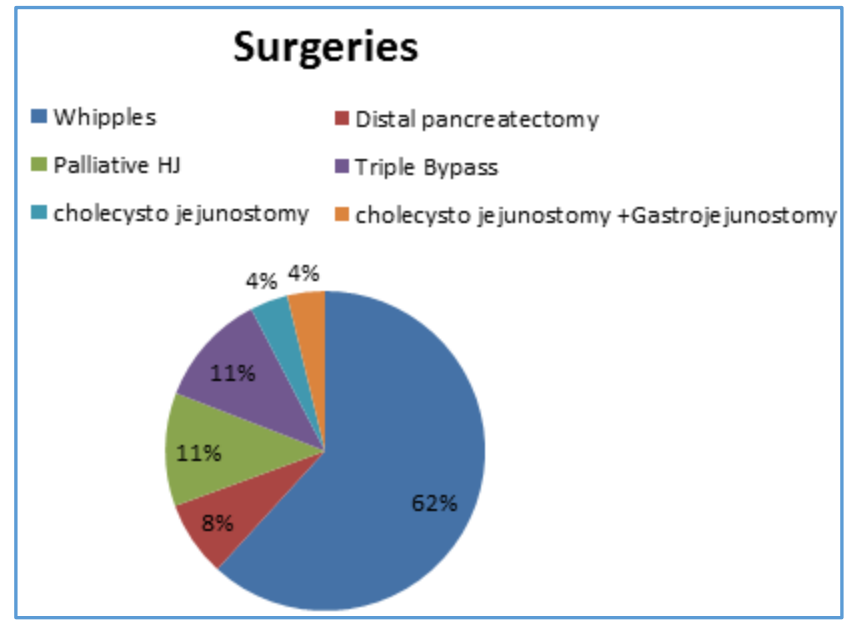

Definitive procedure was done in 18 patients whereas palliative surgery was done in 9 patients who were thought to be operable on initial imaging.

Two patients died in the early post-operative period and these two patients were not taken into account in calculating data regarding enteral feeding and duration of drain removal.

\section{Enteral Feeding}

Of the 16 patients who underwent surgery for pancreatic cancer (pancreatic resections), enteral nutrition was started as early as $3^{\text {rd }}$ day and was delayed in some cases up to 7 days depending on the volume of Ryles aspirate and presence of bowel sounds with a mean duration of around 4.85 days.

\begin{tabular}{|c|c|c|}
\hline $\begin{array}{c}\text { Day of Enteral } \\
\text { Feeding }\end{array}$ & $\begin{array}{c}\text { No. of } \\
\text { Patients }\end{array}$ & $\begin{array}{c}\text { Percentage of } \\
\text { Patients }\end{array}$ \\
\hline$<3$ days & 2 & $12.5 \%$ \\
\hline $4-5$ days & 6 & $42.8 \%$ \\
\hline $6-8$ days & 6 & $42.8 \%$ \\
\hline
\end{tabular}

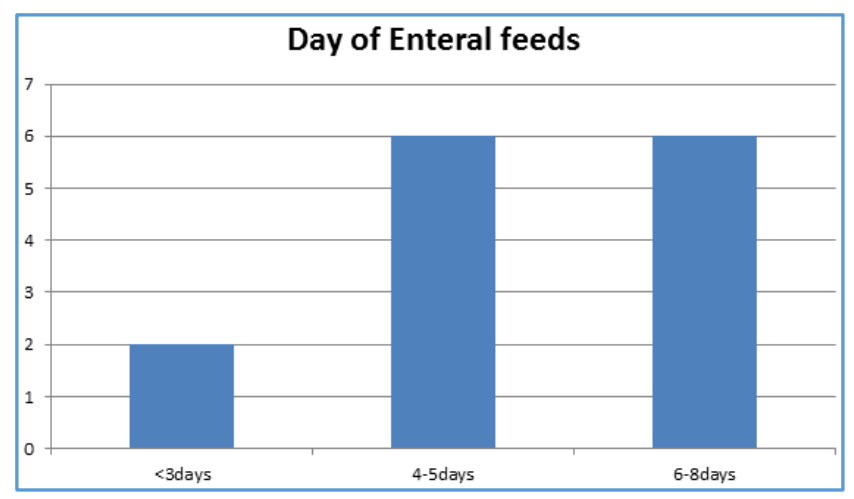

\section{Day of Drain Removal}

Patients with drain less than $30 \mathrm{~mL}$ and serous drain were removed. The average duration for drain removal in my study is 10.71 days.

\begin{tabular}{|c|c|c|}
\hline Day of Drain Removal & No. of Patients & \% of Patients \\
\hline 6 - 10 days & 8 & $57.14 \%$ \\
\hline $11-15$ days & 5 & $35.17 \%$ \\
\hline 16 - 20 days & 1 & $7.14 \%$ \\
\hline
\end{tabular}

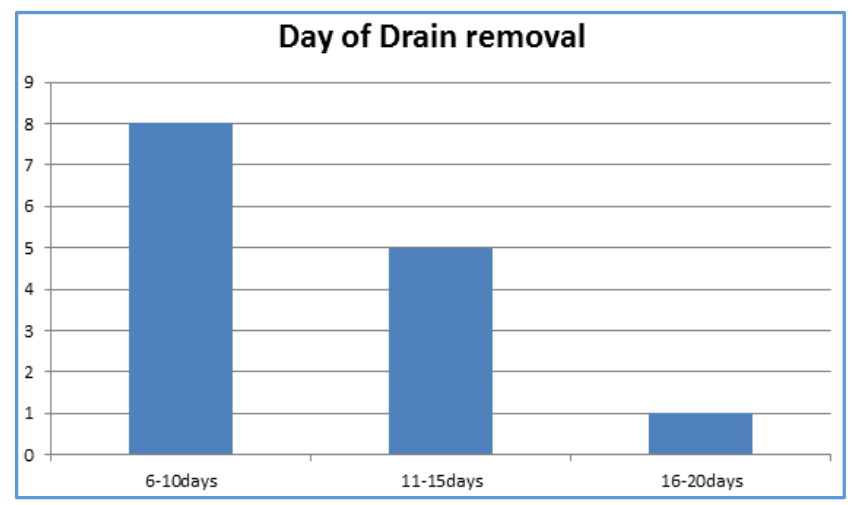

\section{Complications}

The most common complication after pancreatic resections is surgical site infection. Other complications encountered are pancreatic leaks, delayed gastric emptying, reactionary haemorrhage and precipitation of other medical conditions like CCF; 2 patients died in post-operative period $3^{\text {rd }}$ and $6^{\text {th }}$ day.

\begin{tabular}{|c|c|c|}
\hline Complication & $\begin{array}{c}\text { No. of } \\
\text { Patients }\end{array}$ & $\mathbf{\%}$ \\
\hline Surgical site infection & 8 & $50 \%$ \\
\hline Delayed gastric emptying & 2 & $12.5 \%$ \\
\hline Reactionary haemorrhage & 1 & $6.25 \%$ \\
\hline Pancreatic leak & 2 & $12.5 \%$ \\
\hline Death & 2 & $12.5 \%$ \\
\hline $\begin{array}{c}\text { Precipitation of other medical } \\
\text { illnesses }\end{array}$ & 2 & $12.5 \%$ \\
\hline
\end{tabular}

One patient had hypotension and frank blood in drain, so patient was taken up for relaparotomy and diffuse ooze was present and no active bleeder was identified. Abdomen was closed; 6 out of 8 patients who had surgical site infection underwent secondary suturing. Two patients who had pancreatic leak diagnosed by drain fluid amylase greater than 3 times that of serum amylase were managed conservatively. One patient developed CCF and other developed consolidation of basal lobes.

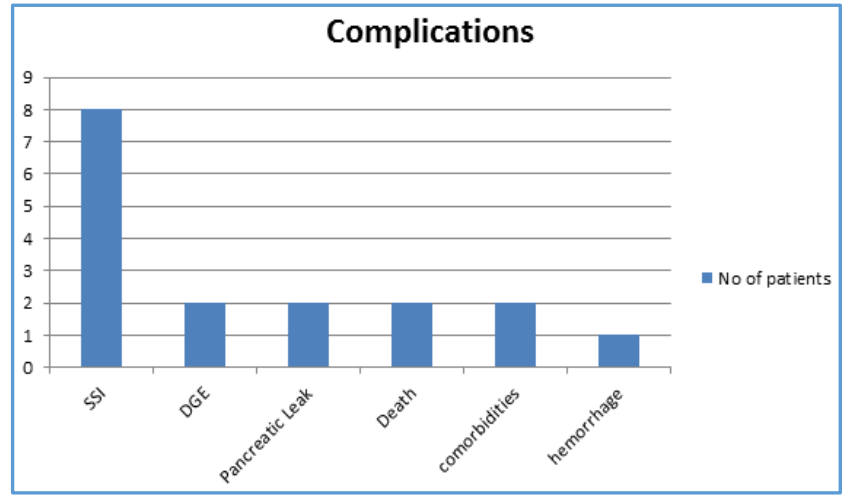

\section{Followup}

Patients who underwent resection and palliation were followed and survival at 6,12 and 18 months was noted; 12 patients are still in followup, of whom 7 belong to the palliation group and 5 belong to the post-resection group. 


\begin{tabular}{|c|c|c|}
\hline Duration & $\begin{array}{c}\text { No. of Patients } \\
\text { Died in } \\
\text { Followup } \\
\text { (Post } \\
\text { Resection) }\end{array}$ & $\begin{array}{c}\text { No. of Patients } \\
\text { Died in } \\
\text { Followup } \\
\text { (Post } \\
\text { Palliation) }\end{array}$ \\
\hline$<6$ months & 2 & 15 \\
\hline 6 months -1 year & 7 & 5 \\
\hline 1 year -1.5 years & 8 & 0 \\
\hline$>1.5$ years & 1 & 0 \\
\hline
\end{tabular}

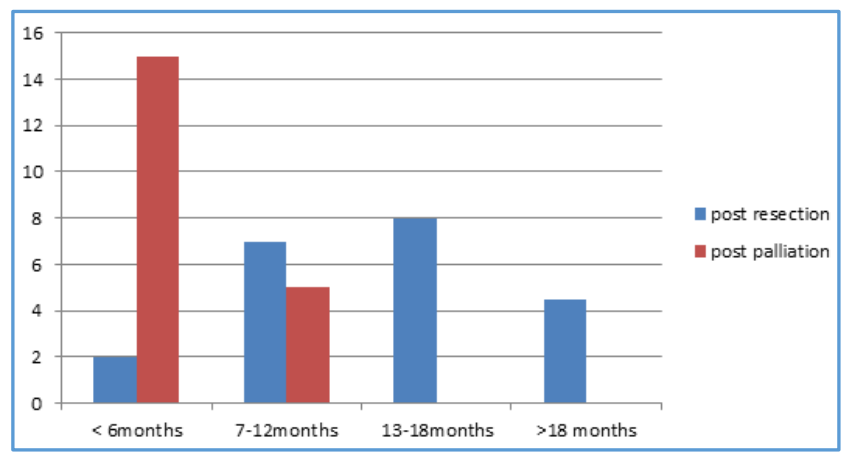

In the present study, the mean survival among the operative group is 11.68 months compared to 4.06 months in palliative group. There is a clear overall survival in patients post resection; 12 patients are still in followup, 7 of whom underwent palliative procedure and patients underwent resection.

\section{DISCUSSION}

\section{Sex Incidence}

\begin{tabular}{|c|c|c|}
\hline Sex & \% in Present Study & Jemal et al, 2009 \\
\hline Male & $23(60.5 \%)$ & $21050(49.5 \%)$ \\
\hline Female & $15(39.5 \%)$ & $21420(51.5 \%)$ \\
\hline
\end{tabular}

Incidence is more common in males in my study compared to other recent studies, which showed increasing trend of pancreatic malignancies in females. This can mostly be attributed to the prevalence of risk factors in males like smoking and alcoholism in my study population. In some studies, men have higher incidence rates than women.(8)

\section{Age Incidence}

The mean age of incidence of pancreatic cancers is 49.71 years, youngest being at the age of 15 years who had pseudopapillary tumour.

\begin{tabular}{|c|c|c|}
\hline & $\begin{array}{c}\text { Present } \\
\text { Study }\end{array}$ & $\begin{array}{c}\text { Horner et al, 2009; } \\
\text { Seer, 2010 }\end{array}$ \\
\hline $\begin{array}{c}\text { Mean age of } \\
\text { incidence }\end{array}$ & 49.71 & 72 yrs. \\
\hline
\end{tabular}

\section{Smoking}

Smoking is associated with increased risk of pancreatic cancer. Smoking contributed for $20 \%$ - $25 \%$ of cases of PDA. (Iodice et al 2008 and Jemal et al 2009). The risk of pancreatic cancer is raised by $75 \%$ as compared to nonsmokers, risk persisting minimum of 10 years after cessation of smoking when the risk gradually diminishes to the baseline.(9) In the present study, 25 out of 38 patients had past history of smoking which is about $65.18 \%$ and 24 out of 38 patients about $63.15 \%$ are alcoholics.
Incidence in Head, Body and Tail

Adenocarcinoma of pancreas is more common in the head region and its incidence is seen in 34 of 38 cases studied and percentage is about $89.4 \%$.

\begin{tabular}{|c|c|c|}
\hline & $\begin{array}{c}\text { Schafer } \\
\text { et al }\end{array}$ & $\begin{array}{c}\text { Present } \\
\text { Study }\end{array}$ \\
\hline $\begin{array}{c}\text { \% of incidence of pancreatic cancer in } \\
\text { head of pancreas }\end{array}$ & $78 \%$ & $89.4 \%$ \\
\hline
\end{tabular}

\section{Clinical Presentation}

The most common presentation of patients with pancreatic malignancies is jaundice followed by loss of weight and appetite followed by pain abdomen. Palpable gallbladder was found only in $50 \%$ of the cases (Courvoisier's law).

\begin{tabular}{|c|c|c|c|c|}
\hline Study & Jaundice & $\begin{array}{c}\text { Pain } \\
\text { Abdomen }\end{array}$ & $\begin{array}{c}\text { Loss of } \\
\text { Weight }\end{array}$ & $\begin{array}{c}\text { Mass } \\
\text { Abdomen }\end{array}$ \\
\hline $\begin{array}{c}\text { Warren et al } \\
(1983)\end{array}$ & 75.90 & 82.80 & 90 & 16.70 \\
\hline $\begin{array}{c}\text { Brook et al } \\
(1981)\end{array}$ & $77 \%$ & $51 \%$ & $55 \%$ & $18 \%$ \\
\hline $\begin{array}{c}\text { Van } \\
\text { Wagensveld } \\
\text { BA et al }\end{array}$ & $90 \%$ & $60 \%$ & $82 \%$ & - \\
\hline Present Study & $87 \%$ & $66 \%$ & $79 \%$ & $50 \%$ \\
\hline
\end{tabular}

\section{Resectability of Tumours}

In tumours around head of pancreas, the resectability was about $44.44 \%$ in our study compared to $42.3 \%$ in study conducted by Akira Nakse et al.

\begin{tabular}{|c|c|c|}
\hline & Akira Nakse et al & Present Study \\
\hline $\begin{array}{c}\text { \% of resectable } \\
\text { tumours }\end{array}$ & $42.3 \%$ & $44.44 \%$ \\
\hline
\end{tabular}

\section{CA19-9}

Ca19-9 is a carbohydrate antigen, which is increased in patients with pancreatic cancers but its specificity is less. It can be elevated in other benign conditions and not elevated in malignancies. It is mainly used for followup to assess recurrence.

\begin{tabular}{|c|c|c|}
\hline & $\begin{array}{c}\text { Berger } \\
\text { et al (2008) }\end{array}$ & $\begin{array}{c}\text { Present } \\
\text { Study }\end{array}$ \\
\hline $\begin{array}{c}\text { Patients with } \\
\text { elevated CA19-9 }\end{array}$ & $66 \%$ & $44.73 \%$ \\
\hline
\end{tabular}

\section{CECT}

Triple phase pancreatic protocol CECT abdomen is the investigation of choice for detecting the respectability of tumour and for accessing the resectability of tumour.

\begin{tabular}{|c|c|c|c|}
\hline & $\begin{array}{c}\text { Present } \\
\text { Study }\end{array}$ & $\begin{array}{c}\text { Bipat et al } \\
\text { (2005) }\end{array}$ & $\begin{array}{c}\text { House et al } \\
\text { (2004) }\end{array}$ \\
\hline $\begin{array}{c}\text { CECT } \\
\text { Sensitivity }\end{array}$ & $76.31 \%$ & $81 \%$ & $80 \%$ \\
\hline
\end{tabular}

\section{Surgical Management}

The main cause of operative death was systemic complication (cardiopulmonary complications) (Bucher et al 2003), in the 
present study 3 patients landed in CCF post-operatively who were managed with diuretics, fluid restriction and inotropic supports and 4 patients developed basal lobe atelectasis. One patient died due to haemorrhage and the other patient died due to CCF.

In patients who underwent pancreatic resections in our institution, mortality rate was around $11.11 \%(2 / 18)$ and morbidity was around $44.46 \%(8 / 18)$. The most common complication is surgical site infection, which needed secondary suturing.

Precipitation of other medical illnesses like cardiac failure, pancreatic leak though seen in 2 patients was selflimiting with medical management.

\begin{tabular}{|c|c|c|}
\hline & $\begin{array}{c}\text { Buchler } \\
\text { et al (2003), } \\
\text { Cameron } \\
\text { et al (2006), } \\
\text { Wagner et al } \\
\mathbf{( 2 0 0 4 )}\end{array}$ & Present Study \\
\hline Mortality & $2 \%$ & $11.11 \%$ \\
\hline Morbidity & $36 \%$ & $44.46 \%$ \\
\hline
\end{tabular}

\section{Mean Survival}

Patients who had a resectable tumour underwent pancreatic resections and they had a better overall survival and disease free survival (11.68 months) compared to the patients who had an advanced disease and considered for palliative therapy (4.065 months). The poor survival in the palliative wing was due to advanced tumour and poor performance status of the patients.

3 patients who underwent ERCP stenting for palliation died on $3^{\text {rd }} 7^{\text {th }}$ and $21^{\text {st }}$ days post procedure.

\begin{tabular}{|c|c|c|}
\hline $\begin{array}{c}\text { Mean Survival in } \\
\text { Months }\end{array}$ & $\begin{array}{c}\text { Conton } \\
\text { et al (2003) }\end{array}$ & $\begin{array}{c}\text { Present } \\
\text { Study }\end{array}$ \\
\hline Post Resection & 14.3 months & 11.68 months \\
\hline Post Palliation & 4.9 months & 4.065 months \\
\hline
\end{tabular}

\section{CONCLUSION}

- A study was carried on patients with pancreatic malignancies who were admitted to surgical wards of Govt. General Hospital, Rangaraya Medical College, Kakinada from July 2014 to November 2016.

- Males compared to females suffered more in the ratio of 23:15.

- There is steady increase in the incidence of pancreatic malignancies with age with peak incidence between 50 60 yrs.

- Jaundice followed by loss of weight and loss of appetite are the most common symptoms.

- Elevated bilirubin with palpable gallbladder is seen in $50 \%$ of cases only.

- USG abdomen is a useful screening method for identification of dilated CBD and presence or absence of mass lesion of pancreas and to see for any distension of gallbladder.

- Dilated CBD with mass in the head of pancreas is the most common imaging finding.

- Most of the patients present late and more than half (52.63\%) presented with a metastatic disease.

- Pancreatic protocol CECT abdomen is used for determining preoperative resectability and had significant false positives $(9 / 25)$.

- Most common surgery done in our Department is PPPD, followed by distal pancreatectomy and high number of palliative procedures.

- Surgeries for pancreatic malignancies have high morbidity due to the poor patient reserve and advanced stage of presentation.

- Even after a successful resection of the tumour, in followup the 1 year survival rate is $55.55 \%$.

- Due to the advanced presentation, most of the patients have poor outcome following pancreatic surgeries. So high index of suspicion should guide towards USG screening in elderly patients with $\mathrm{H} / \mathrm{O}$ smoking and loss of weight and appetite with or without jaundice.

\section{REFERENCES}

[1] Morgagni GB. De sedibus, et causis morborum per anatomen indagatis libri quinque venetis. Typog Remondiniana 1761.

[2] Da Costa JM. On the morbid anatomy and symptoms of cancer of the pancreas. Philadelphia, JB. Lippincott \& Company, 1858.

[3] Halsted WS. Contributions to the surgery of the bile passages, especially of the common bile duct. Boston Med Surg J 1899;141:645-54.

[4] Kausch W. Das carcinoma der papilla duodeni und seine radikale entfernung. Beitr Z Klin Chir 1912;78:439-86.

[5] Hirschel G. Die resection des duodenums mit der papille wegen karzinoms. Munch Med Wochenschr 1914;61:1728-9.

[6] Moertel CG, Childs DS, Reitemeier RJ, et al. Combined 5fluorouracil and supervoltage radiation therapy of locally unresectable gastrointestinal cancer. Lancet 1969;2(7626):865-7.

[7] Burris HA, Moore MJ, Anderson J, et al. Improvements in survival and clinical benefit with gemecitabine as first line therapy for patients with advanced pancreas cancer: a randomized trial. J Clin Oncol 1997;15(6):2403-13.

[8] Yadav D, Lowenfels AB. The epidemiology of pancreatitis and pancreatic cancer. Gastroenterol 2013;144(6):1252-61.

[9] Iodice S, Gandini S, Maisonneuve P, et al. Tobacco and the risk of pancreatic cancer: a review and metaanalysis. Langenbecks Arch Surg 2008;393(4):535-45. 